\title{
The Use of Angulated Screw Channel Abutment System for Anterior Single-Implant Restorations: A Clinical Report
}

\author{
Anterior Tek Diş İmplant Restorasyonlarında Açılı Vida Kanallı Abutmant Sisteminin Kullanımı
}

Bahar GURPINAR (D), Gül Merve YALÇIN ÜLKER @ D, Önjen TAK (D)

Öz

$\mathrm{Bu}$ olgu raporunun amac1; aç1lı vida kanallı ti-base abutmantlarla desteklenen hibrit abutmant kuronların kullanım amacı ve avantajlarını açıklamaktır. İmplant dişhekimliği'nde açılı vida kanallı abutmantlar, açılı implantlar üzerine uygulanan vidalı kuronlarda estetik bölgede vida kanalının gözükmesi problemine çözüm olarak üretilmişlerdir. Ayrıca, açılı vida kanallı ti-base abutmantlarla oluşturulan hibrit abutmant kuronlar, anterior tek diş implant restorasyonlarında estetik ve mekanik direnç avantajlarını birleştirilen bir yöntem olarak da düşünülebilir. Hibrit abutmant kuron dizaynında açılı vida kanalı sisteminin kullanımı, fazla açılı yerleştirilmiş implantların vidalı kuronlar ile restorasyonunda klinisyenlere optimal estetik ve dayanıklılık avantajlarını sunar.

Anahtar Kelimeler: Açılı vida kanalı, hibrit abutmant, hibrit abutmant kuron, ti-base, açılı implant.

Bahar GURPINAR(四)

Assistant Prof. Dr., Department of Prosthodontics, Faculty of Dentistry, Okan University, Istanbul, Turkey

e-mail: bahar.gurpinar@okan.edu.tr

Gül Merve YALÇIN ÜLKER

Assistant Prof. Dr., Department of Oral Surgery, Faculty of Dentistry, Okan University, Istanbul, Turkey

Önjen TAK

Associated Prof. Dr., Department of Prosthodontics, Faculty of Dentistry, Okan University

Submitted / Gönderilme: 29.11.2019

Accepted / Kabul:25.06.2020

\begin{abstract}
The purpose of this clinical report is to explain the use and advantages of hybrid abutment crowns supported by ti-base abutments with Angulated Screw Channel (ASC) for anterior single-implant restorations. ASC system abutments have recently released to market as a solution of visible screw access problem in the esthetic zone. Moreover, using hybrid abutment consists of ti-base abutment with ASC system and esthetic materials may be a new method to combine esthetic and mechanical strength advantages for anterior single implant restorations. The use of ASC system with hybrid abutment crown design may allow clinicians to obtain optimal esthetics and mechanical strength in the case of over-angulated implants.
\end{abstract}

Keywords: angulated screw channel, hybrid abutment, hybrid abutment crown, ti-base, over-angulated implants, visible screw access.

\section{Introduction}

Restoration of anterior single tooth deficiencies with implant therapy has been a common and valid option for decades. Nowadays, parallel with developments on implant dentistry area, implant-supported restorations should satisfy patient's all expectations about function and esthetic. The important esthetic parameters of implant supported restorations are peri-implant soft tissue contour and emergence profile of implant supported restoration that depends on implant position. However, because of anatomy of anterior maxilla and sometimes poor bone volume, it may not always be possible to place an implant with ideal angulation that allows a screw retained restoration. Because of esthetic concerns, screw retained restorations could be preferred when screw access hole could be located in a non-visible area. Common solution of this problem is preferring cemented restoration that have disadvantages as excess cement and lack of removability (1), (2), (3), (4), (5). 
Angulated screw channel (ASC) abutment systems were first introduced to market by Talladium International Implantology and the name of 'dynamic abutment' in 2004. Implant angulation could be corrected up to 28 degrees to make the angulation ideal for screw retention with no need to an additional component. After this, ASC abutment systems have been manufactured by other several companies. Straumann, Dentsply Astra Tech, Nobel Biocare (Branemark system, Replace, Standard and Multiunit abutments), Biomet 3i, BTI, Phibo TSA, Eckerman, Zimmer, Klockner, DIO, and Ankylos are implant companies that compatible with this abutment system that can adjust the implant angulation up to 25 degrees from original implant axis. Thus, a visible screw access channel can be avoided and a screw retained restoration can be used without esthetic concerns. Moreover, with ASC abutment system's angulated screw, it may not be necessary to widen the head of screw access hole for proper engagement of screw driver. Widening the head of screw hole leads to reduce thickness of ceramic material and thereby weaken it (2), (3), (5).

For anterior single implant restorations, abutment material and design are critical factors for mechanical strength and esthetic. Hybrid zirconia abutments with a titanium base (ti-base) is found stronger than monolithic zirconia abutments. At the same time using titanium abutments without an esthetic material can cause gray discoloration of peri-implant mucosa especially in patients with thin tissue (3), (6). Hybrid abutments are recommended with its similar esthetic characteristics with zirconia abutments and also similar mechanical properties with titanium abutments. Thanks to thicker ceramic layer, hybrid abutments show positive esthetic results (7).

There is a lack of information in the literature about clinical use of hybrid abutment crowns. In this clinical report, the use of hybrid abutment crown by ti-base with ASC system abutment is showed with a proper case.

\section{Technique}

A 30-year-old male and systemically healthy patient applied to Istanbul Okan University Dental Hospital for the treatment of tooth \#21. After the clinical and radiographic evaluation, the extraction of the tooth and an early implant placement was determined (Fig 1). Following the tooth extraction, the edentulous space was restored with a fibersupported Maryland bridge during the healing period. After bone healing, a Straumann Bone Level implant (3.3 x 10 $\mathrm{mm}$ ), was placed and peri-implant bone defects were grafted with bone (Creos $1 \mathrm{~g}$ ) and covered with collagen membrane (Creos 15x20 mm) (Fig 2). Because of inadequate insertion torque, implant couldn't be loaded immediately. After osseointegration, implant healing abutment was removed and a screw-retained provisional crown was fabricated for peri-implant soft tissue conditioning for about six weeks and thereafter a custom impression coping was prepared to transfer the emergence profile and final contour of soft tissues accurately to the impression (Fig 3,4,5). Polyether (Impregum, 3M Espe) was used as impression material with a standard closed tray. Because of the deep placement and labial inclination of the implant, a standard cement and/or screw-retained restoration couldn't be the proper solution for a long-term esthetic, biological and mechanical success. Thus, a special all-ceramic hybrid abutment crown supported by a ti-base abutment with a special angulated screw and ASC (Straumann Variobase for Crown AS) was used to modify the crown axis palatal to the implant axis up to $25^{\circ}$ by avoiding a buccal screw access point. Hybrid abutment crown was consisted of a ti-base with ASC system, zirconia as mesostructure and esthetic veneer full ceramic layer (IPS e.max) prepared with cut-back technique. Transferring model to digital stage, designing and manufacturing of the crown, trying on the patient with intraoral and radiographic control and cementation stages were completed (fig 6,7,8,9,10). No biological, mechanical or esthetic complications were encountered during the 1-year follow-up period.

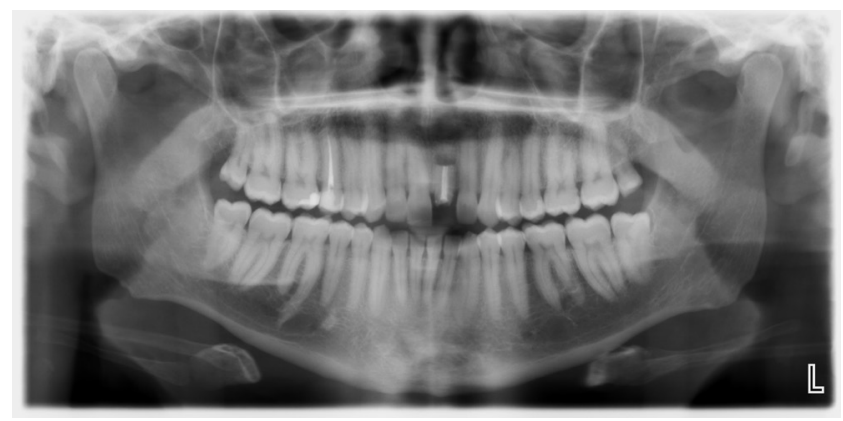

Figure 1: First panoramic radiography of patient 


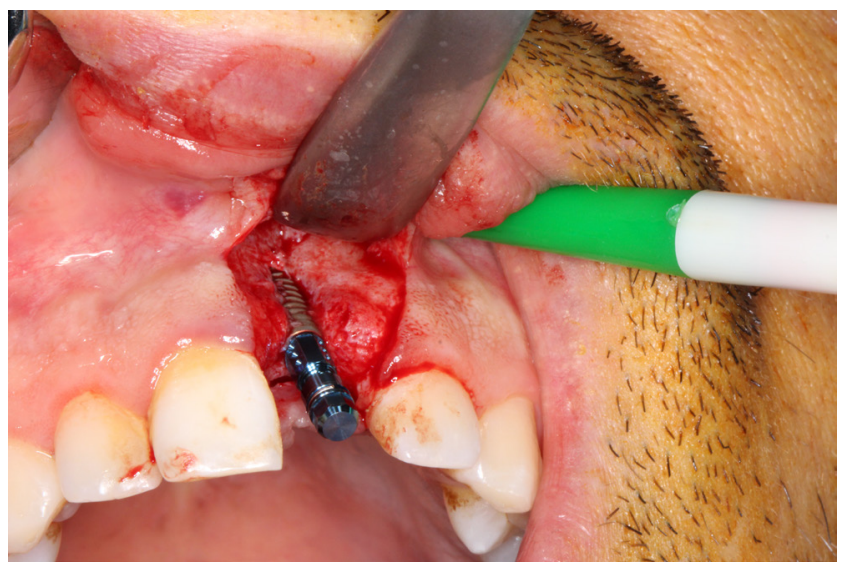

Figure 2: Implant placement during surgery

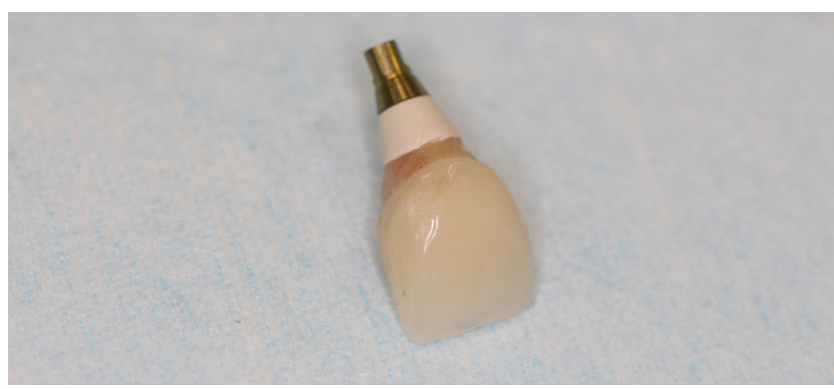

Figure 3: Screw-retained provisional crown

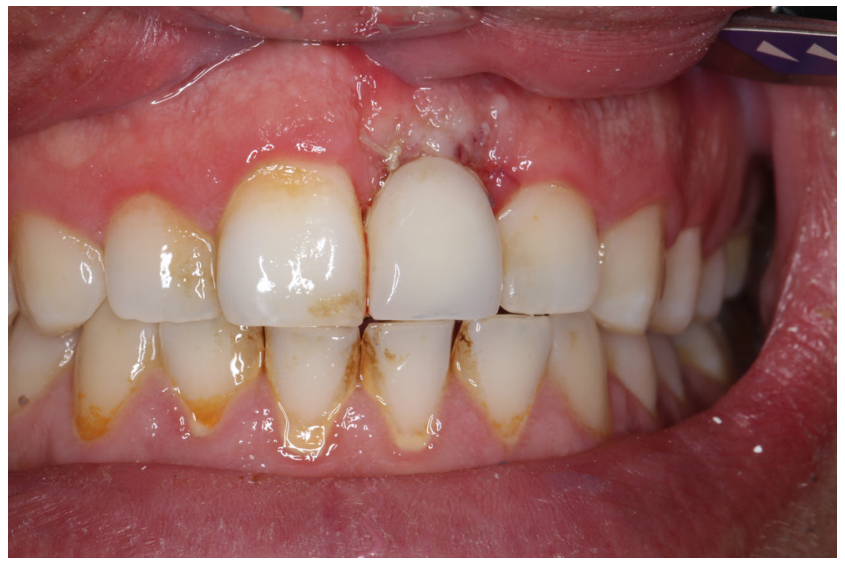

Figure 4: First placement of screw-retained provisional crown

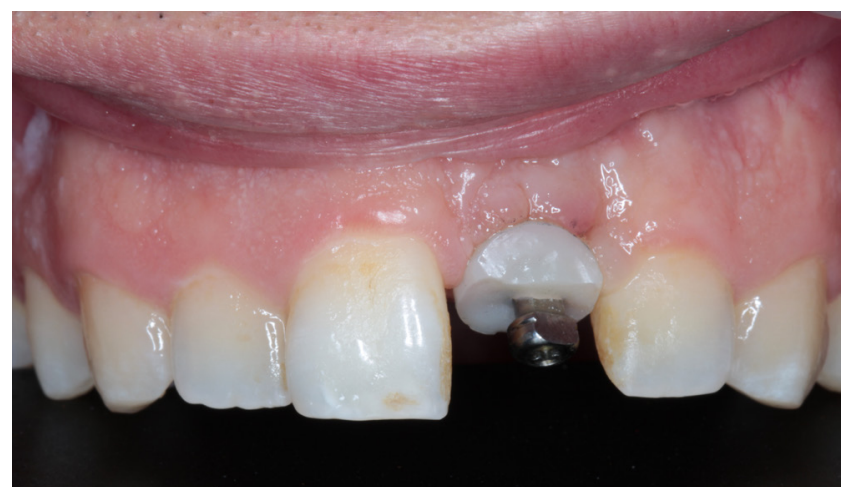

Figure 5: Emergence profile and soft tissue contours after six weeks
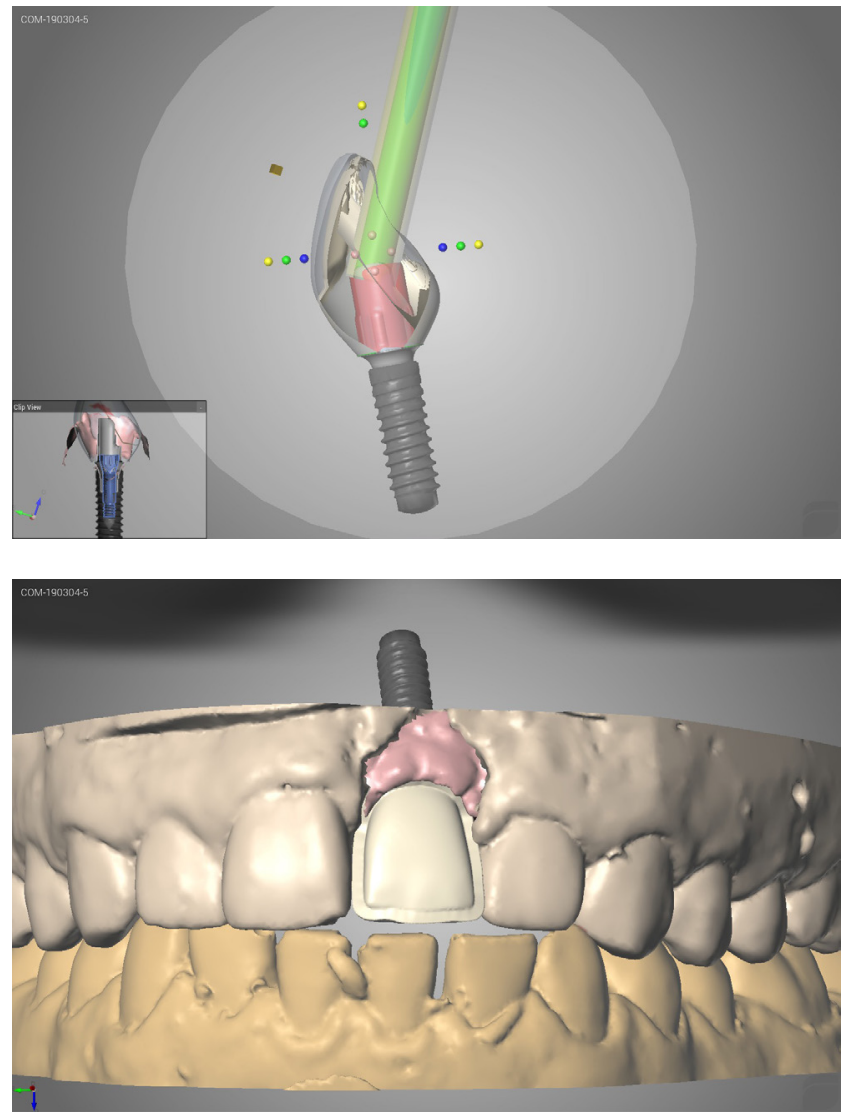

Figure 6,7: Designing stage of the permanent crown 

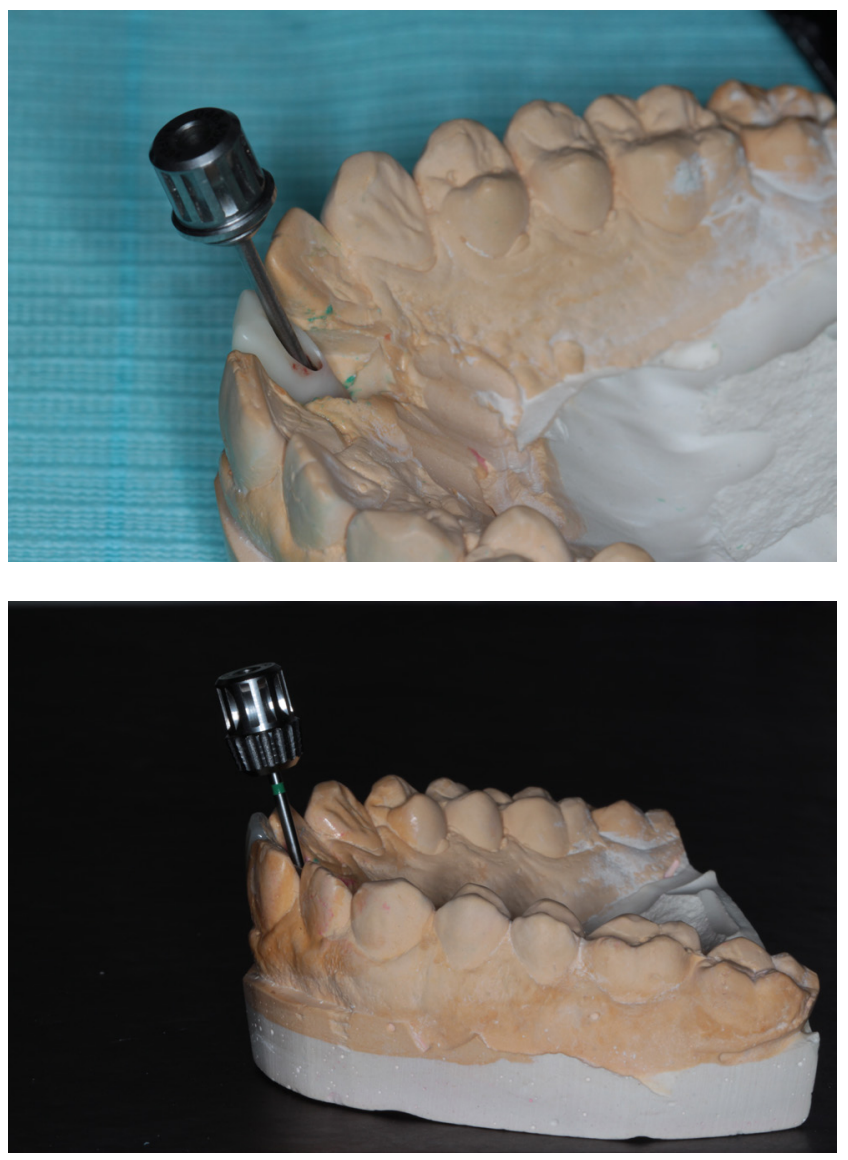

Figure 8,9: Correction of over-angulation with ASC abutment

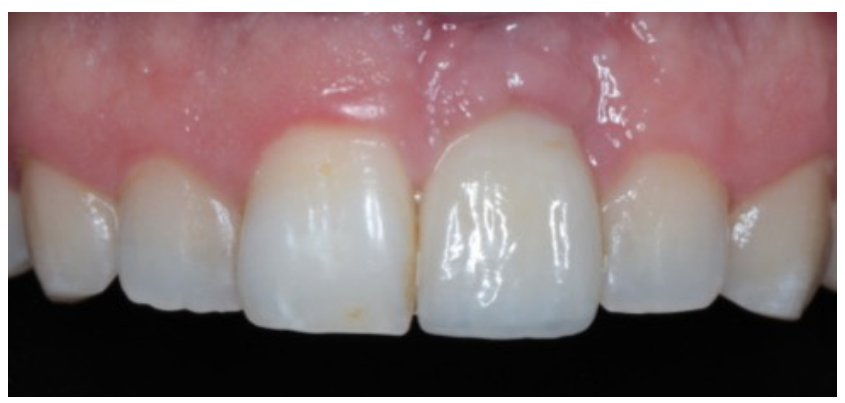

Figure 10: Final view of the hybrid-abutment crown

\section{Discussion}

The aim of this study is to make a literature review, collect actual data about angulated abutments and support these knowledges with a case. Main concerns about the usage of angulated abutments are possibility of causing more stress and bone loss around implants than straight abutments, thereby increase of prosthetic complications and decrease of implant survival. In a review study, Cavallaro and Greenstein have indicated that although finite element analysis and strain gauge studies presented more stress on prostheses and bone than straight abutments survival studies have not indicated decrease of prosthetic and implant survival. Moreover, no additional bone loss and screw loosening were detected for implants that supported with angled abutments (8).

In a prospective study in 2018, Friberg and Ahmadzai investigated outcomes of straight walled implant with conical connection (Nobel Parallel CC) and rate of need for ASC with reasons for anterior maxilla. In this study, 42 of 49 implants required abutments with ASC system. There were some reasons for this high rate. At first; anatomy of maxilla, form and direction of bone resorption after tooth loss often don't let an esthetically sufficient screw retained restoration. There may be bone concavities that affect implant site preparation and lead to increase on the need of more labial directions of implant to avoid buccal fenestrations. Another way to handle with this problem is using cemented restorations (2), (4).

In a prospective study conducted by Wilson in 2009; 39 patients received 42 single tooth implants in five years period. All 42 implants had symptoms of peri-implant disease at initial treatment. Excess cement was found at peri implant site in 34 of them (\%81). These symptoms were eliminated with removing excess cement around implants (9).

Other goals of screw retained restorations are solving problems about implant restorations with ease of removal, reduced cost and chair time. All prosthodontists in the study conducted by Friberg and Ahmadzai in 2018 have no negative experience about ASC; no major complications were encountered in 5 years follow up period (2), (4).

In the point of choosing best material combination for hybrid abutment crowns, Tribst et al in 2018 have emphasized that although materials with high elastic modulus like zirconia can generate higher stress, it would not fracture before other materials and it shows less chance of catastrophic failure. Other interesting finding of this study is possibility of using materials with low elastic modulus like hybrid ceramics for hybrid abutment crowns. Hybrid abutment crowns manufactured with hybrid ceramic material have presented better stress distribution on cement line and looks like the best material choice. 


\section{Conclusion}

The present case and current literature knowledge showed that, use of hybrid abutment crowns which consist of ti-base with ASC and esthetic materials for anterior single tooth implant restorations is a successful way that can tolerate implant angulation up to 25 degrees, simplifies screw access with its angulated screw and gives positive esthetic and mechanic results.

\section{References}

1. Asgeirsson AG, Sailer I, Gamper F, Jung RE, Hämmerle CHF, Thoma DS. Veneered zirconia abutments cemented on non-original titanium bases: 1-year results of a prospective case series. Clin Oral Implants Res. 2019;0-3.

2. Berroeta E, Zabalegui I, Donovan T, Chee W. Dynamic Abutment: A method of redirecting screw access for implantsupported restorations: Technical details and a clinical report. J Prosthet Dent. 2015;113(6):516-9.

3. Sakamoto S, Ro M, Al-Ardah A, Goodacre C. Esthetic abutment design for angulated screw channels: A technical report. J Prosthet Dent [Internet]. 2018;119(6):912-5.
4. Friberg B, Ahmadzai M. A prospective study on single tooth reconstructions using parallel walled implants with internal connection (NobelParallel CC) and abutments with angulated screw channels (ASC). Clin Implant Dent Relat Res. 2019;21(2):226-31.

5. Garcia-Gazaui S, Razzoog M, Sierraalta M, Saglik B. Fabrication of a screw-retained restoration avoiding the facial access hole: A clinical report Presented at the American Prosthodontics Society Annual Meeting, Chicago, Ill, February 2015. J Prosthet Dent. 2015;114(5):621-4.

6. Schepke U, Gresnigt MMM, Browne WR, Abdolahzadeh S, Nijkamp J, Cune MS. Phase transformation and fracture load of stock and CAD/CAM-customized zirconia abutments after 1 year of clinical function. Clin Oral Implants Res. 2019;(December 2017):559-69.

7. TRIBST JPM, PIVA AM de OD, BORGES ALS, BOTTINO MA. Influence of crown and hybrid abutment ceramic materials on the stress distribution of implant-supported prosthesis. Rev Odontol da UNESP. 2018;47(3):149-54.

8. Cavallaro J, Greenstein G. Angled implant abutments: A practical application of available knowledge. J Am Dent Assoc. 2011;142(2):150-8.

9. Wilson Jr. TG. The Positive Relationship Between Excess Cement and Peri-Implant Disease: A Prospective Clinical Endoscopic Study. J Periodontol . 2009;80(9):1388-92. 